\title{
Feeding canola meal to dairy cows: A meta-analysis on lactational responses
}

\author{
R. Martineau, D. R. Ouellet, and H. Lapierre ${ }^{1}$ \\ Dairy and Swine Research and Development Centre, Agriculture and Agri-Food Canada, Sherbrooke, Québec, Canada J1M 0C8
}

\begin{abstract}
The objective of this meta-analysis was to determine the effects of the substitution of a protein source by canola meal $(\mathrm{CM})$ on lactational responses $(\mathrm{CM}$ minus control) in dairy cows. The study included 49 comparisons of isonitrogenous ( $\pm 1.0 \%$ dietary $\mathrm{CP}$ content) dietary treatments published since 1975 (27 experiments). The CM intake ranged from 1.0 to $4.0 \mathrm{~kg} / \mathrm{d}$ (standard deviation $=0.65$ ). Regressions were forced through the origin, weighted by sample size, and controlled for changes in dry matter intake and in dietary concentrations of CP and ether extract. Milk yield and milk protein yield responded positively to the substitution of a protein source by CM. The response in milk protein yield was affected by the type of protein source that was substituted; the positive response was half less when CM was substituted for soybean meal compared with substitution of CM for other protein sources. The latter effect was in part related to a positive response on milk protein percentage when CM replaced protein sources other than soybean meal. The response in efficiency of $\mathrm{N}$ utilization (milk $\mathrm{N}$ yield/ $\mathrm{N}$ intake) was positive to the substitution of a protein source by CM. Negative changes in supply of metabolizable protein (MP) estimated from the 2001 National Research Council model were associated with positive responses in milk protein yield with CM substitution, a finding contrary to the expected positive relationship between supply of MP and milk protein yield. In conclusion, a protein supplement can be substituted by CM with positive effects on milk and milk protein production. These data also indicate an underestimation of MP supply associated with CM inclusion in dairy rations using the National Research Council model.
\end{abstract}

Key words: canola meal, meta-analysis, metabolizable protein, milk

Received May 16, 2012.

Accepted November 4, 2012.

${ }^{1}$ Corresponding author: Helene.Lapierre@agr.gc.ca

\section{INTRODUCTION}

Cruciferous seeds and plants contain glucosinolates, which can yield breakdown products potentially goitrogenic, hepatotoxic, or pungent (Fenwick, 1982). Goitrogenic compounds reduce the availability of iodine to the animal and diminish the synthesis of thyroxine, which is involved in the hormonal mechanisms of milk production (Grenet and Journet, 1971). A lower grain intake was also reported with diets containing rapeseed meal high in glucosinolate, tannin, or phytate content (Papas et al., 1978; Thomke, 1981). Therefore, this type of rapeseed meal was not considered a suitable feedstuff for livestock (Abbadi and Leckband, 2011).

In 1969, a low-glucosinolate trait was identified in the Polish rapeseed spring variety Bronowski and that discovery started an international backcrossing breeding program to introduce the new trait into high-yielding erucic acid-free rapeseed varieties (Abbadi and Leckband, 2011). A few years later, Canadian plant breeders were able to license the first rapeseed cultivar with low levels of both glucosinolates and erucic acid (Tower; Stefansson and Kondra, 1975). The term canola was coined to specifically identify rapeseed varieties containing less than $2 \%$ erucic acid in the oil portion and less than $30 \mu \mathrm{mol}$ of glucosinolates/g in the meal portion (i.e., double-zero or double-low rapeseed; Bell, 1984; Newkirk, 2009).

Since the mid 1980s, Canadian canola producers have consistently grown more canola in a greater area than ever before (Harker et al., 2012). Consequently, the use of its coproduct, canola meal (CM), also increased tremendously as a ruminant feed in Canada (Christensen and McKinnon, 1989) as well as in other countries (Emanuelson, 1989; Tuori, 1992; Huhtanen, 1998; Moss, 2002; Tan et al., 2011). In Western Canada and parts of the United States, CM is the principal source of protein for dairy cow diets because it is readily available and provides a high-quality protein (Hickling, 2008; Mulrooney et al., 2009).

Over the years, many manuscripts have been published comparing lactational performances of dairy cattle obtained with $\mathrm{CM}$ and other protein supplements, especially soybean meal (SBM). In an extensive review, Hill (1991) concluded that rapeseed meal low 
in glucosinolates could be used as freely as SBM and that milk production and composition were equally satisfactory from either protein supplement. More recently, Huhtanen et al. (2011) provided evidence that milk production was as good or better and that milk protein secretion was higher with CM compared with SBM in grass silage-based diets. Positive responses in milk protein yield might be related to an improved efficiency of microbial synthesis and reduced ruminal CP degradability, based on the findings of a meta-analysis on omasal studies (Broderick et al., 2010). As suggested by NRC (2001), the estimated supply of MP, either from RUP or microbial protein, is the main factor that determines milk protein secretion in lactating dairy cows.

Therefore, the first objective of this meta-analysis was to evaluate lactational performances when CM substituted another protein source in dairy rations. The second objective was to determine if lactational responses were affected by experimental conditions or factors such as the type of forage in the diet or the protein source that was substituted. A third objective was to evaluate if changes in milk protein yield were in line with changes in estimated supply of MP (NRC, 2001).

\section{MATERIALS AND METHODS}

\section{Database}

A comprehensive literature review was conducted in October 2011 and updated in February 2012 to track experiments in which CM (or a low-glucosinolate rapeseed meal) was replaced by another protein supplement in dairy cows. A large body of literature was compiled after a thorough search of computerized-stored databases [e.g., Scopus (http://www.scopus.com/home.url), PubMed (http://www.ncbi.nlm.nih.gov/pubmed), and Canola Council database (http://www.canolacouncil. org/research/)]. References in articles and review manuscripts were scrutinized in the search for new articles. The literature search was not limited to studies published in North American journals or to publications in the English language.

Four a priori criteria were used to select eligible studies: (1) $\mathrm{N}$ intake reported, (2) isonitrogenous diets [i.e. difference in dietary $\mathrm{CP}$ concentration not exceeding $1.0 \%$ (DM basis) between the control and the $\mathrm{CM}$ diets], (3) no CM in the control diet and a proportion of $\mathrm{CM}$ of 0.05 (DM basis) or more in the treated diet, and (4) treated diets with a high proportion of CM in the protein supplement portion of the diet. For the latter criterion, a protein supplement was defined as a concentrate feed with a CP concentration of $20 \%$ or more (DM basis) and a high proportion of CM was defined as
0.85 or more (weight basis) or 0.75 or more ( $\mathrm{N}$ basis). The breakpoint was set at 0.85 to ensure a minimal bias of responses by the complementary protein source in the treated diets.

Among the eligible studies, some were deemed outliers and excluded from the database for the reasons outlined below. The heat-damaged and dark-colored CM used in the study of Fisher and Walsh (1976) was excluded because it depressed the apparent DM digestibility and the lactational performances. Initial milk production was low (i.e., $13.5 \mathrm{~kg} / \mathrm{cow}$ per day) in the study of Khorasani et al. (1994) and diets had a low CP concentration (i.e., 12.5\%) in the study of Munger (1996) compared with the other studies in the database; therefore, these 2 studies were also excluded from the eligible database. The study of Mancuso et al. (2002) had a large gap between its dietary proportion of CM (i.e., 30\%) and the upper proportion of CM in the database (i.e., 17.2\%; Table 1); therefore, that study was not included in the database. Finally, the ureabased diet (1.9\% DM) in Brito and Broderick (2007) reduced DMI and lactational performances compared with other diets based on true protein sources; that urea-based diet was also excluded from the database.

With the exception of Rinne et al. (2006), authors of all eligible manuscripts were contacted to confirm the use of $\mathrm{CM}$ before inclusion of the experiment in the database if the glucosinolate concentration of the rapeseed meal was not specified in the article. The final database contained 27 experiments (88 diets) reported in 22 publications using these exclusion criteria: Ingalls and Sharma (1975), Laarveld and Christensen (1976), Sharma et al. (1977), Papas et al. (1978), DePeters and Bath (1986), Robinson and Kennelly (1988), Huhtanen et al. (1991), Macleod (1991), McClean and Laarveld (1991), Tuori (1992), Emanuelson et al. (1993), Huhtanen et al. (1995), Piepenbrink et al. (1998), Dewhurst et al. (1999), Khalili et al. (2001), Shingfield et al. (2001), Vanhatalo et al. (2003), Rinne et al. (2006), Brito and Broderick (2007), Mulrooney et al. (2009), Christen et al. (2010), and Oba et al. (2010).

\section{Rations and Nitrogen Fractions of Canola Meal}

Dietary characteristics of rations were estimated using the NRC (2001) model with feed ingredients as similar as possible to those reported in the publications. The chemical composition of each feed ingredient was used when reported [e.g., CP, NDF, ADF, ether extract (EE), ash, and $\mathrm{N}$ fractions]; otherwise, table values of NRC (2001) were used.

Nitrogen fractions of CM were required to estimate MP supply. The oil extraction process affects the N fractions and the rumen CP degradability of CM. The 
Table 1. Descriptive statistics of intakes of protein source and canola meal (CM); dietary proportion of CM, $\mathrm{CP}$, and ether extract $(\mathrm{EE})$ in control $(\mathrm{Ctrl})$ and $\mathrm{CM}$ diets; and the difference between diets $(\Delta ; \mathrm{CM}$ minus $\mathrm{Ctrl})^{1}$

\begin{tabular}{|c|c|c|c|c|c|c|}
\hline Variable $^{2}$ & Diet & $\mathrm{n}^{3}$ & Mean & SD & Minimum & Maximum \\
\hline \multirow[t]{3}{*}{ Protein source (kg/cow per day) } & Ctrl & 44 & 2.0 & 0.93 & 0.7 & 5.0 \\
\hline & $\mathrm{CM}$ & 44 & 2.3 & 0.65 & 1.0 & 4.0 \\
\hline & $\Delta$ & 49 & +0.43 & 0.599 & -1.80 & 1.10 \\
\hline \multirow[t]{3}{*}{ CM intake (kg/cow per day) } & Ctrl & 44 & 0.0 & 0.00 & 0.0 & 0.0 \\
\hline & $\mathrm{CM}$ & 44 & 2.3 & 0.65 & 1.0 & 4.0 \\
\hline & $\Delta$ & 49 & +2.40 & 0.713 & 1.04 & 4.01 \\
\hline \multirow[t]{3}{*}{ CM proportion (100 g/kg, DM basis) } & Ctrl & 44 & 0.0 & 0.00 & 0.0 & 0.0 \\
\hline & CM & 44 & 1.17 & 0.267 & 0.51 & 1.72 \\
\hline & $\Delta$ & 49 & +1.17 & 0.267 & 0.51 & 1.72 \\
\hline \multirow[t]{3}{*}{ CP (\%, DM basis) } & Ctrl & 44 & 16.6 & 1.56 & 14.0 & 20.3 \\
\hline & $\mathrm{CM}$ & 44 & 16.4 & 1.57 & 13.6 & 20.1 \\
\hline & $\Delta$ & 49 & 0.00 & 0.371 & -0.75 & 1.00 \\
\hline \multirow[t]{3}{*}{$\mathrm{EE}(\%, \mathrm{DM}$ basis $)$} & $\bar{C}$ trl & 44 & 3.70 & 0.972 & 1.96 & 5.72 \\
\hline & $\mathrm{CM}$ & 44 & 3.75 & 1.019 & 2.09 & 6.11 \\
\hline & $\Delta$ & 49 & +0.19 & 0.364 & -0.80 & 1.07 \\
\hline
\end{tabular}

${ }^{1} \Delta=\mathrm{CM}$ diet mean minus Ctrl diet mean. A positive value represents an increase in response to CM and a negative value a decrease.

${ }^{2}$ Protein source was defined as a concentrated feed containing at least $20 \%$ CP (DM basis).

${ }^{3}$ Overall, the database included 88 different treatment means that generated 49 pairs of Ctrl and CM.

processing method of CM, either mechanical or solvent extraction (Khorasani et al., 1994), was seldom reported in the publications. When missing, the processing method of CM was assumed to be mechanical extraction with no heating, unless the oil content was reported and was less than $4 \%$, in which case CM was presumed to be solvent extracted (Lusas and Riaz, 2005). Nitrogen fractions of CM or rapeseed meal from in situ methodology and published in NRC (2001) were used to estimate rumen $\mathrm{CP}$ degradability when not reported in the manuscript. Data reported in Table 15-1 of NRC (2001) for the unheated mechanically extracted CM and data reported in Table 15-2b of NRC (2001) for the heated mechanically extracted $\mathrm{CM}$ and the solvent-extracted rapeseed meal (unheated or heated) were used. It should be pointed out that data reported in Table 15-2b of NRC (2001) are for less commonly used feedstuffs and, therefore, means are less reliable because they are derived from a fewer number of observations.

\section{Meta-Analyses}

Coding of Data. This meta-analysis was conducted on responses $(\Delta$ : the value from the $\mathrm{CM}$ diet minus the value from the control diet). A publication could contain more than 1 feeding trial or experiment and each experiment could contrast more than $1 \mathrm{CM}$ diet to 1 or more control diets. For example, Brito and Broderick (2007) compared CM with solvent-extracted SBM and cottonseed meal (the urea diet was excluded based on previous criteria); therefore, 2 isonitrogenous pairs of diets were constituted by coupling SBM and cottonseed meal with CM. As previously mentioned, a pair of diets was deemed isonitrogenous as long as the difference in dietary CP content did not exceed 1.0\% (DM basis). From the 88 diets in the final database, 49 pairs of control and treated diets were generated.

Responses. Responses included DMI in $\mathrm{kg} /$ cow per day; yields of milk, 4\% FCM (Gaines, 1928), and ECM (Sjaunja et al., 1990) in kilograms per cow per day; percentages of milk protein, fat, and lactose; yields of milk protein, fat, and lactose in grams per cow per day; feed efficiency (ECM/DMI, $\mathrm{kg} / \mathrm{kg}$ ); and apparent $\mathrm{N}$ efficiency ( $\mathrm{N}$ in milk/ $\mathrm{N}$ intake, $\mathrm{g} / \mathrm{kg}$ ). Yields of milk protein, fat, and lactose, as well as feed and apparent $\mathrm{N}$ efficiencies were calculated from milk production, milk percentages, and intake data. Production data in Khalili et al. (2001) were kindly provided by P. Huhtanen (Swedish University of Agricultural Sciences, Umeå, Sweden, personal communication).

Independent Covariates. The explanatory covariate of interest was the dietary proportion of $\mathrm{CM}$ and was forced in each model. The dietary proportion of $\mathrm{CM}$ was expressed in $100 \mathrm{~g} / \mathrm{kg}$ (DM basis); therefore, the coefficients of CM presented in the current study represent the response expected for each increment of 1 unit of $10 \%$ inclusion of $\mathrm{CM}$ in the ration (e.g., 2 $\mathrm{kg}$ of $\mathrm{CM}$ per $20 \mathrm{~kg}$ of DMI). Other units of CM were explored to report the results [e.g., intake of CM $(\mathrm{kg} / \mathrm{d}$, DM basis), intake of $\mathrm{N}$ from $\mathrm{CM}$ (g/d), and proportion of $\mathrm{CM}$ in the concentrate]. Given that the $\mathrm{CP}$ content of CM was reported only in half the publications, $\mathrm{N}$ intake from CM could not be used as the unit of CM. 
Furthermore, expressing the unit of $\mathrm{CM}$ as the proportion of $\mathrm{CM}$ in the diet (DM basis) appeared to be the best choice because DMI and the amount of CM ingested were reported in all experiments and the ratio took into account the differences in DMI that existed among trials.

Besides CM, the independent covariates also included differences in DMI $(\Delta \mathrm{DMI})$ and in dietary $\mathrm{CP}$ concentration $(\Delta \mathbf{C P})$ because both covariates were reported in all experiments and could act as potential confounders. Differences in dietary EE concentration $(\Delta \mathbf{E E})$ were also considered as a covariate. These were reported in $60 \%$ of experiments, whereas $\Delta \mathrm{EE}$ were estimated using the NRC (2001) model in the other $40 \%$. To determine if $\Delta \mathrm{EE}$ should be added or not to the models of the whole database, $\Delta \mathrm{EE}$ was first tested in the subset database of experiments that reported $\Delta \mathrm{EE}$ (i.e., $60 \%$ of experiments). If $\Delta \mathrm{EE}$ was a significant covariate (i.e., $P \leq 0.10$ ), then it was added to the models of the whole database; if not significant, then the models in the whole database only included the following independent covariates: $\mathrm{CM}, \Delta \mathrm{DMI}$, and $\Delta \mathrm{CP}$. By controlling for $\Delta \mathrm{DMI}, \Delta \mathrm{CP}$, and $\Delta \mathrm{EE}$, the responses to $\mathrm{CM}$ substitution were assumed to be at equal DMI and equal dietary $\mathrm{CP}$ and $\mathrm{EE}$ concentrations.

Factors. Each response was analyzed in relation to experimental conditions or factors that could explain some within-experiment variability (e.g., type of protein source substituted, main type of forage in the diet, and origin of the study). The type of protein source substituted was encoded into 2 classes: SBM as a single source ( $\mathrm{n}=16$ studies or 23 experiments) or other protein sources (e.g., corn gluten meal, cottonseed meal, distillers product, or a mixture of more than 1 protein source including SBM; $\mathrm{n}=13$ studies or 26 experiments). The main type of forage was categorized into 2 classes: grass and (or) legume ( $\mathrm{n}=16$ studies or 30 experiments) or other forages (e.g., corn or barley silage, alone or mixed with a similar proportion of grass or legume forage; $\mathrm{n}=11$ studies or 19 experiments). The origin of publication was encoded into 2 classes: North America ( $\mathrm{n}=17$ studies or 27 experiments) or Europe ( $\mathrm{n}=10$ studies or 22 experiments). Other factors were analyzed but are not reported in this paper because they had minor influence on the responses (e.g., stage of lactation, $\mathrm{CP}$ and concentrate levels in the control diet, initial milk production level, and initial milk protein and fat concentrations).

Statistical Model. Regressions between the responses and the amount of inclusion of CM were forced through the origin (i.e., no intercept in the model) because responses were assumed to be zero when CM was zero (Glasser et al., 2008). Indeed, coefficients of
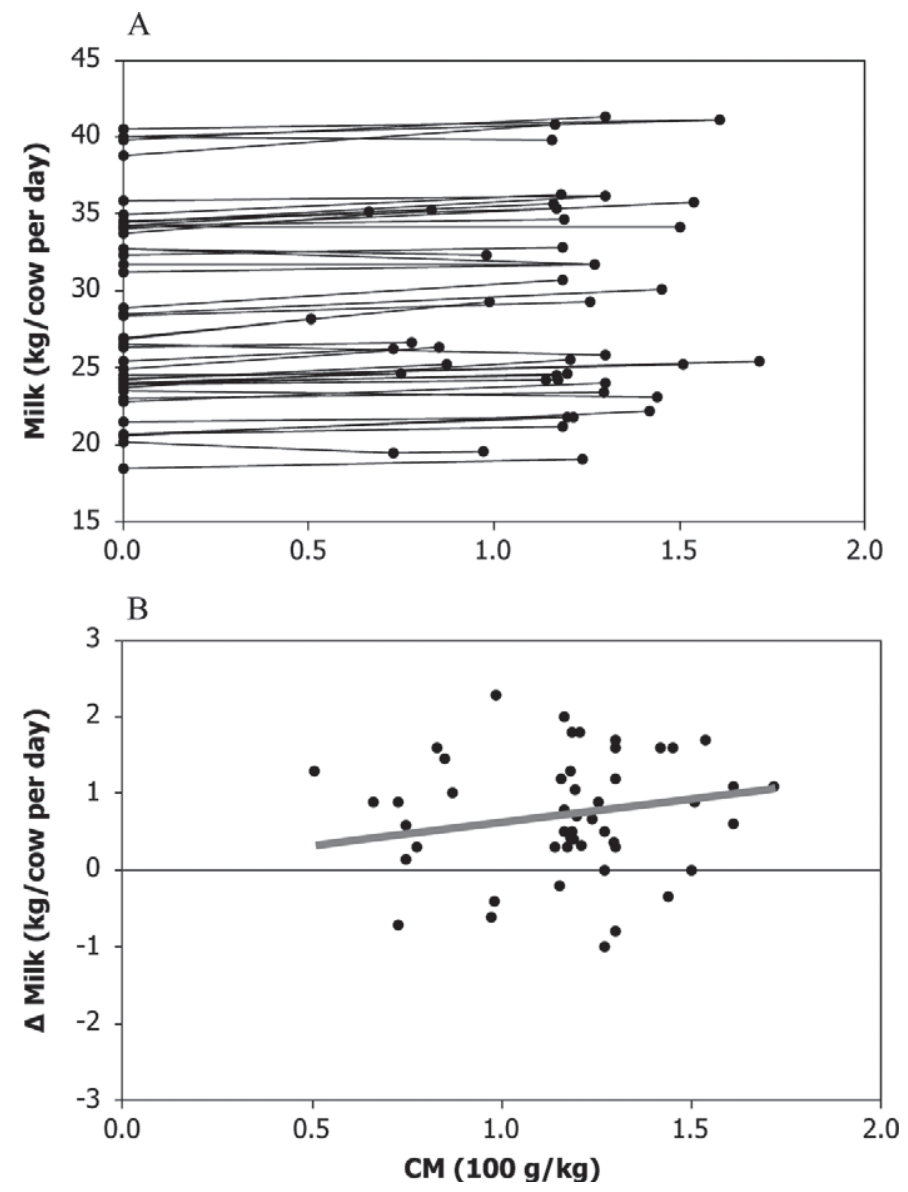

Figure 1. Positive within-experiment relationship between milk yield $(\mathrm{kg} / \mathrm{cow}$ per day) and the dietary proportion of canola meal (CM; $100 \mathrm{~g} / \mathrm{kg}$, DM basis) based on absolute values (Milk) or based on responses ( $\Delta$ Milk; $\mathrm{CM}$ diet minus control diet, where each point represents a pair of joined data from panel A). $P$-value in superscript: panel A: Milk $=+0.62^{\leq 0.001}( \pm 0.083) \times \mathrm{CM}+28.8^{\leq 0.001}( \pm 0.07) ; \mathrm{n}=$ 98; panel B: $\Delta$ Milk $=+0.62 \leq^{0.001}( \pm 0.084) \times \mathrm{CM} ; \mathrm{n}=49$.

CM are similar whether obtained from a regression of response values or from a within-experiment analysis on absolute values (Figure 1A and B). Only linear relationships could be determined in the within-experiment analysis because only 1 study had more than 2 data points (i.e., Robinson and Kennelly, 1988).

All regressions were weighted by the number of cows in the $\mathrm{CM}$ diet. The covariates $\Delta \mathrm{DMI}, \Delta \mathrm{CP}$, or $\Delta \mathrm{EE}$ were excluded from the model if not significant $(P>$ $0.10)$ or if the variance inflation factor indicated multicollinearity. Furthermore, significant covariates other than CM were deleted from the model as long as they did not modify meaningfully the coefficient of CM (Kleinbaum et al., 1998). Outliers were identified by evaluating their influence on Cook's distance (Cook, 1979) and were removed if they changed the relationship. Graphical examinations were used at each stage of the meta-analysis to detect extreme data. 
Each experimental condition or factor was tested separately. A categorical factor was deemed significant if the $P$-value of the interaction between the factor and $\mathrm{CM}$ was $\leq 0.10$; upon significance, the database was divided by the classes of the factor and the response was retested in each subset database as described previously. The independence of distribution of CM diets across the classes of 2 factors was tested with the Pearson chi-square test. Residual values (i.e., differences between model-predicted and measured value of the studied parameter) were evaluated graphically to assess the extent to which each model accounted for the variation in the observed data. Because the experimental conditions were not randomly distributed and were specific to each study, variables were considered as fixed factors; therefore, the range of inference for this meta-analysis is limited to the domain of the specific experiments in the data set (Sauvant et al., 2008). All analyses were conducted with Minitab (version 16.1.1.0, 2010; Minitab Inc., State College, PA). For comparison purpose, mixed models of SAS (Littell et al., 1996) with study as a random effect were conducted and root mean squared errors (RMSE) were adjusted for random study effects as described by St-Pierre (2001).

The project was submitted to and approved by the Institutional Committee for Animal Care of the Sherbrooke Research Centre (Quebec, Canada), although no animals were required for this study.

\section{RESULTS}

\section{Meta-Design}

The composition of $\mathrm{CM}$ was reported in half the publications and was similar to that of the mechanically extracted CM in NRC (2001): $\mathrm{CP}=39.4 \pm 3.65 \%$ (range: 32.3 to $44.1 \%$; $\mathrm{n}=14$ ); $\mathrm{NDF}=27.7 \pm 5.85 \%$ (range: 19.9 to $37.1 \% ; \mathrm{n}=9$ ); $\mathrm{ADF}=18.2 \pm 2.39 \%$ (range: 12.9 to $21.0 \% ; \mathrm{n}=13$ ); and $\mathrm{EE}=5.0 \pm 3.40 \%$ (range: 1.1 to $11.7 \% ; \mathrm{n}=12$ ).

Descriptive statistics of diet composition and of lactational performances of cows fed control diets (no $\mathrm{CM}$ ) and $\mathrm{CM}$ diets, and the resulting responses to the substitution of a protein source by $\mathrm{CM}$ are listed in Tables 1 and 2, respectively. The number of control and $\mathrm{CM}$ diets is lower than the number of differences or responses because control and $\mathrm{CM}$ diets included only unrepeated diets (refer to coding of data). The withinexperiment relationships in all experiments and among significant factors are presented in Table 3.

As mentioned previously, mixed regression model analyses were also performed for comparison purposes (Supplemental Table 1, available online at http://www. journalofdairyscience.org/). Responses were similar in fixed and mixed analyses when the same independent covariates were included in the models. Differences between fixed and mixed models were detected only on milk fat responses because different covariates were retained in the final models. Milk fat concentration did not respond to $\mathrm{CM}$ substitution in the fixed model because $\Delta \mathrm{EE}(P=0.073)$ was also retained in the final model; on the other hand, milk fat concentration responded negatively to $\mathrm{CM}$ substitution in the mixed model, as $\triangle \mathrm{EE}$ was not significant. Milk fat yield responded positively to $\mathrm{CM}$ substitution in the fixed model (Table 3) but not in the mixed model, as $\triangle \mathrm{DMI}$ $(P<0.001)$ and $\Delta \mathrm{CP}(P=0.050)$ were also retained in the final model. Based on the results observed between both approaches and on the fact that variables were coined as fixed factors in our meta-analysis, only results from the fixed regression models are reported and discussed in the article.

Overall, the daily intake of $\mathrm{CM}$ did not exceed 4.0 $\mathrm{kg} /$ cow and the CM proportion in the treated diets averaged $11.7 \%$ of total DMI or 1.17 (SD 0.267) when the unit was expressed as $100 \mathrm{~g} / \mathrm{kg}$ (Table 1). The dietary proportion of $\mathrm{CM}$ did not exceed $17.2 \%$ in the database. As a prerequisite for inclusion of studies in the database, the proportion of $\mathrm{CM}$ in the protein supplement portion of CM needed to be above 0.85 in all diets; in fact, it was 1.00 in all diets except 5 .

\section{Analysis of Lactational Responses}

Hereafter, "response to the substitution of a protein source by CM" will be referred more conveniently as "response to substitution." As mentioned previously, the coefficients of CM in Table 3 are the responses associated with each increment of $100 \mathrm{~g}$ of $\mathrm{CM} / \mathrm{kg}$ of diet (DM basis) or 10\% CM in the diet at equal DMI and equal dietary $\mathrm{CP}$ and $\mathrm{EE}$ concentrations. In the text below, responses are also discussed for a cow fed the maximum proportion of $\mathrm{CM}$ in the database (i.e., $17.2 \%)$.

DMI. Responses in DMI were mostly positive (35 out of 49). Responses in DMI to substitution increased $(P<0.001)$ on average by $0.24 \mathrm{~kg} /$ cow per day per $10 \%$ of $\mathrm{CM}$ inclusion in the ration; therefore, DMI would increase by $0.41 \mathrm{~kg} /$ cow per day for a cow fed a diet with $17.2 \%$ of CM.

Yields of Milk, 4\% FCM, and ECM, and Milk Efficiency. Most milk yield responses were positive (42 out of 49; Figure 1, panel B). As a result, milk yield responded positively $(P<0.001)$ to the substitution of a protein supplement by CM (Table 3). In line with the response in milk yield, $4 \%$ FCM, ECM, and milk efficiency $(\triangle \mathrm{ECM} / \mathrm{DMI})$ also responded positively $(P<0.001)$ to substitution (Table 3$)$. For a cow fed 
Table 2. Descriptive statistics of lactational performance in control (Ctrl) and canola meal (CM) diets, and the resulting responses to substitution of a protein source by $\mathrm{CM}(\Delta ; \mathrm{CM} \text { minus } \mathrm{Ctrl})^{1}$

\begin{tabular}{lllcccc}
\hline Variable $^{2}$ & Diet & $\mathrm{n}^{3}$ & Mean & $\mathrm{SD}$ & Minimum & Maximum \\
\hline DMI (kg/cow per day) & $\mathrm{Ctrl}$ & 44 & 20.3 & 2.84 & 15.2 & 26.0 \\
& $\mathrm{CM}$ & 44 & 20.1 & 2.62 & 14.7 & 25.7 \\
& $\Delta$ & 49 & +0.29 & 0.508 & -1.1 & 1.6 \\
MY (kg/cow per day) & $\mathrm{Ctrl}$ & 44 & 29.3 & 6.20 & 18.4 & 40.5 \\
& $\mathrm{CM}$ & 44 & 28.9 & 6.36 & 19.1 & 41.4 \\
& $\Delta$ & 49 & +0.73 & 0.774 & -1.0 & 2.3 \\
4\% FCM (kg/cow per day) & $\mathrm{Ctrl}$ & 44 & 28.6 & 5.33 & 19.7 & 36.9 \\
& $\mathrm{CM}$ & 44 & 28.0 & 5.80 & 19.3 & 38.5 \\
ECM (kg/cow per day) & $\Delta$ & 49 & +0.52 & 0.848 & -1.3 & 2.6 \\
& $\mathrm{Ctrl}$ & 44 & 28.5 & 5.34 & 19.5 & 36.9 \\
Protein (\%) & $\mathrm{CM}$ & 44 & 27.9 & 5.70 & 19.5 & 37.6 \\
& $\Delta$ & 49 & +0.52 & 0.798 & -1.2 & 2.3 \\
MPY (g/cow per day) & $\mathrm{Ctrl}$ & 44 & 3.19 & 0.188 & 2.84 & 3.58 \\
& $\mathrm{CM}$ & 44 & 3.23 & 0.185 & 2.83 & 3.51 \\
Fat (\%) & $\Delta$ & 49 & +0.016 & 0.0659 & -0.11 & 0.15 \\
& $\mathrm{Ctrl}$ & 44 & 927 & 175.7 & 593 & 1,260 \\
MFY (g/cow per day) & $\mathrm{CM}$ & 44 & 926 & 178.8 & 639 & 1,282 \\
& $\Delta$ & 49 & +28.7 & 28.03 & -28 & 97 \\
Lactose (\%) & $\mathrm{Ctrl}$ & 44 & 3.90 & 0.550 & 2.84 & 5.08 \\
& $\mathrm{CM}$ & 44 & 3.83 & 0.526 & 2.42 & 4.89 \\
MLY (g/cow per day) & $\Delta$ & 49 & -0.048 & 0.154 & -0.42 & 0.31 \\
& $\mathrm{Ctrl}$ & 44 & 1,126 & 214.3 & 760 & 1,422 \\
ECM/DMI (kg/kg) & $\mathrm{CM}$ & 44 & 1,097 & 238.0 & 743 & 1,466 \\
Milk N/N intake (g/kg) & $\Delta$ & 49 & +15.1 & 46.32 & -78 & 135 \\
& $\mathrm{Ctrl}$ & 33 & 4.85 & 0.163 & 4.42 & 5.05 \\
& $\mathrm{CM}$ & 29 & 4.84 & 0.159 & 4.38 & 5.00 \\
& $\Delta$ & 34 & -0.022 & 0.0478 & -0.13 & 0.07
\end{tabular}

${ }^{1} \Delta$ is the change in response of each dependent variable to the substitution of a protein source by CM. A positive value represents an increase in response to $\mathrm{CM}$ and a negative value a decrease.

${ }^{2}$ Dry matter intake, MY = milk yield, 4\% FCM (Gaines, 1928), and ECM (Sjaunja et al., 1990) in kilograms per cow per day; protein, fat, and lactose = percentages of milk protein, fat, and lactose; MPY, MFY, and $\mathrm{MLY}=$ yields of milk protein, fat, and lactose; ECM/DMI = efficiency of milk production; milk $\mathrm{N} / \mathrm{N}$ intake = apparent $\mathrm{N}$ efficiency.

${ }^{3}$ Overall, the database included 88 individual treatment means that generated 49 pairs of Ctrl and CM (for milk lactose $\%$ and yield: 62 treatment means and 34 pairs).

$\mathrm{CM}$ at $17.2 \%$ in the diet, yields of milk, $4 \% \mathrm{FCM}$, and ECM would increase by $1.07,0.85$, and $0.84 \mathrm{~kg} /$ cow per day, respectively, and milk efficiency would increase by $0.035 \mathrm{~kg} / \mathrm{kg}$.

Milk Composition. Overall, the response in milk protein percentage was positive $(P<0.02)$ and would increase by $0.034 \%$ for a cow fed $\mathrm{CM}$ at $17.2 \%$ in the diet (Table 3). Milk fat percentage did not respond to CM substitution but tended to be associated negatively with changes in $\mathrm{EE}$ concentrations $[P$-value in superscript: $\Delta \mathrm{EE}:-0.02^{\mathrm{NS}}( \pm 0.0020) \times \mathrm{CM}-0.11^{0.07}$ $\left.( \pm 0.058) \times \Delta \mathrm{EE}\left(\mathrm{R}^{2}=0.18 ; \mathrm{n}=48\right)\right]$. This effect could result from alterations in rumen biohydrogenation of dietary PUFA (Bauman and Griinari, 2003).
Conversely to the response in milk protein percentage, the response in milk lactose percentage was negative $(P$ $=0.001$ ) and would decrease by $0.038 \%$ for a cow fed $\mathrm{CM}$ at $17.2 \%$ in the diet.

Yields of Milk Components and Apparent $N$ Efficiency. Responses in yields of milk protein and fat to substitution were positive $(P \leq 0.002$; Table 3$)$. For a cow fed $\mathrm{CM}$ at $17.2 \%$ in the diet, milk protein and fat yields would increase by 45 and $28 \mathrm{~g} / \mathrm{cow}$ per day, respectively. The response in milk protein yield is better due to the combined positive effect on milk yield and milk protein percentage. The response in apparent $\mathrm{N}$ efficiency $(\Delta$ milk $\mathrm{N} / \mathrm{N}$ intake) to substitution was positive $(P<0.001)$ mainly due to the positive effect 
Table 3. Lactational responses to substitution of a protein supplement by canola meal (CM) in the full database (All) and in databases separated by the classes of significant experimental conditions or factors ${ }^{1}$

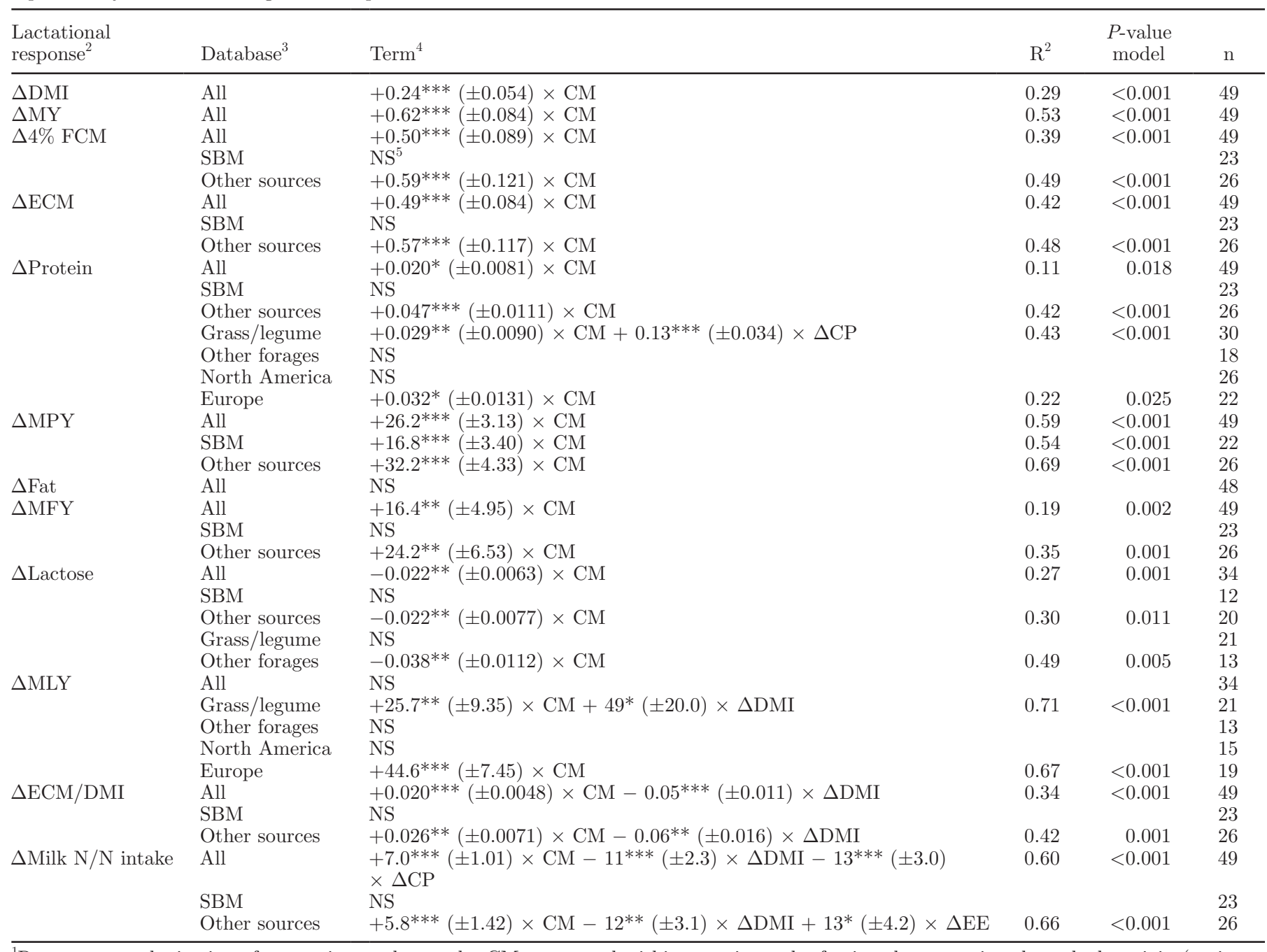

${ }^{1}$ Response to substitution of a protein supplement by CM was tested within experiment by forcing the regression through the origin (no intercept); regressions were weighted by sample size and controlled for differences in DMI $(\Delta \mathrm{DMI})$ and in dietary concentrations of $\mathrm{CP}(\Delta \mathrm{CP})$ and ether extract $(\Delta \mathrm{EE})$. Only factors where the $P$-value of interaction with $\mathrm{CM}$ was $\leq 0.10$ and models where the $P$-value of $\mathrm{CM}$ was $\leq 0.10$ are presented.

${ }^{2} \Delta=\mathrm{CM}$ diet mean minus control diet mean; DMI, MY = milk yield, 4\% FCM (Gaines, 1928), and ECM (Sjaunja et al., 1990) in kilograms per cow per day; protein, fat, and lactose = percentages of milk protein, fat, and lactose; MPY, MFY, and MLY = yields of milk protein, fat, and lactose in grams per cow per day; ECM $/ \mathrm{DMI}=$ efficiency of milk production $(\mathrm{kg} / \mathrm{kg}) ;$ milk $\mathrm{N} / \mathrm{N}$ intake $=$ apparent $\mathrm{N}$ efficiency $(\mathrm{g} / \mathrm{kg})$.

${ }^{3}$ Database used: full database (All) or subset database restricted to the experiments for each class of factor. Factors $=$ type of protein: soybean meal (SBM) as a single source or other protein sources (e.g., corn gluten meal, cottonseed meal, and distillers product); type of forages: grass and (or) legume or other forages (e.g., corn or barley silage, alone or mixed with a grass or legume forage); origin of publication: North America or Europe.

${ }^{4} \mathrm{CM}=$ dietary proportion of $\mathrm{CM}(100 \mathrm{~g} / \mathrm{kg}$, DM basis); the coefficient of CM represents the response associated with an increment of $10 \%$ CM in the diet, DM basis; ${ }^{* * *} P \leq 0.001,{ }^{* *} P \leq 0.01,{ }^{*} P \leq 0.05$ (SE in parenthesis).

${ }^{5} \mathrm{NS}=$ equation is not reported when $\mathrm{CM}$ is not significant $(P>0.10)$.

on milk protein secretion (Table 3). The apparent $\mathrm{N}$ efficiency would increase by $12 \mathrm{~g}$ of milk $\mathrm{N} / \mathrm{kg}$ of $\mathrm{N}$ intake for a cow fed CM at $17.2 \%$ in the diet.

\section{Analysis of Factors}

Type of Protein Source. Several lactation parameters were affected by the type of protein source that was substituted by CM. The response in milk yield to substitution was not affected by the type of protein source; however, responses in $4 \% \mathrm{FCM}$ and ECM to substitution were positive only in experiments in which $\mathrm{CM}$ replaced protein sources other than SBM $\left(P_{\text {interaction }}\right.$ $=0.092$ and 0.061 for $4 \%$ FCM and ECM, respectively; Table 3). The response in milk protein percentage to 
substitution was positive only in experiments using protein sources other than SBM $\left(P_{\text {interaction }}<0.001\right.$; Figure 2 ); accordingly, the response in milk protein yield to substitution was positive but 2 times higher in experiments using protein sources other than SBM compared with those using SBM $\left(P_{\text {interaction }}=0.010\right.$; Table 3$)$. In line with responses in $4 \% \mathrm{FCM}$ and ECM, the response in milk fat yield to substitution was positive only in experiments using protein sources other than SBM compared with those using $\mathrm{SBM}\left(P_{\text {interaction }}=0.027\right.$; Table 3). The response in milk lactose percentage to substitution was negative only in experiments using protein sources other than $\mathrm{SBM}\left(P_{\text {interaction }}=0.035\right.$; Table 3); consequently, the response in milk lactose yield was not affected by the type of protein source.

The response in milk efficiency and in apparent $\mathrm{N}$ efficiency to substitution were positive only in experiments using protein sources other than SBM ( $P_{\text {interaction }}$ $=0.10$ and 0.040 , respectively; Table 3 ), in accordance with earlier findings on the response in ECM and in milk protein yield to substitution.

Type of Forage. The main type of forage in the diet affected the responses in milk protein and lactose percentages to substitution. Milk protein percentage responded positively to substitution only in experiments based on grass and (or) legume forages $\left(P_{\text {interaction }}=\right.$ 0.008; Table 3 and Figure 3). The response in milk lactose percentage to substitution was negative only in studies based on corn or barley silage, alone or mixed with a grass or legume forage $\left(P_{\text {interaction }}=0.005\right.$; Table $3)$; as a result, the response in milk lactose yield to

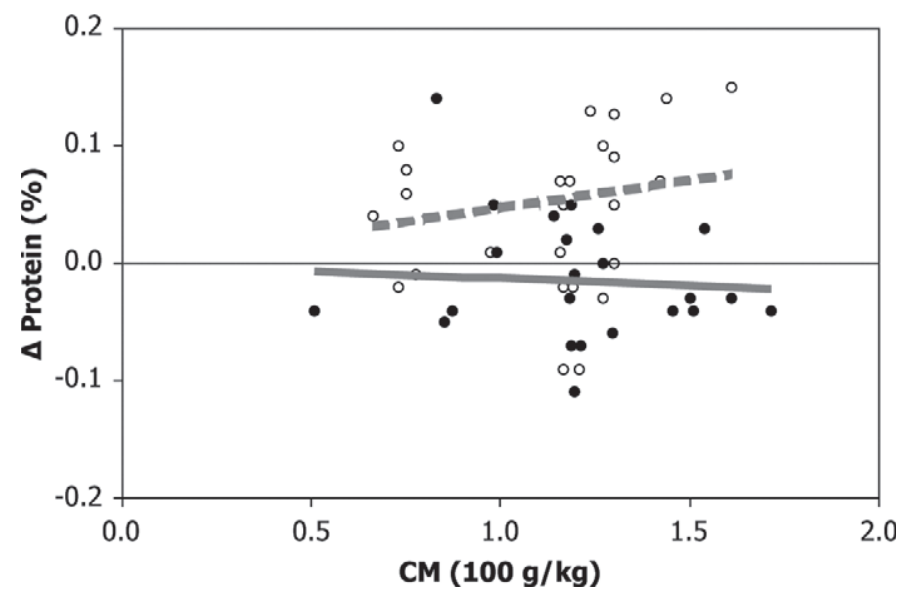

Figure 2. Effect of type of protein substituted by canola meal $(\mathrm{CM})$ on responses in milk protein percentage $[\Delta$ Protein $(\%)$; CM diet minus control diet] $\left(P_{\text {interaction }}<0.001\right)$ : soybean meal $[\bullet$ and solid line; $P$-value in superscript: $\left.-0.01^{0.11}( \pm 0.008) \times \mathrm{CM} ; \mathrm{R}^{2}=0.11 ; \mathrm{n}=23\right]$ versus other protein sources $\left[\bigcirc\right.$ and dotted line; $+0.05^{\leq 0.001}( \pm 0.011) \times$ $\left.\mathrm{CM} ; \mathrm{R}^{2}=0.42 ; \mathrm{n}=26\right]$.

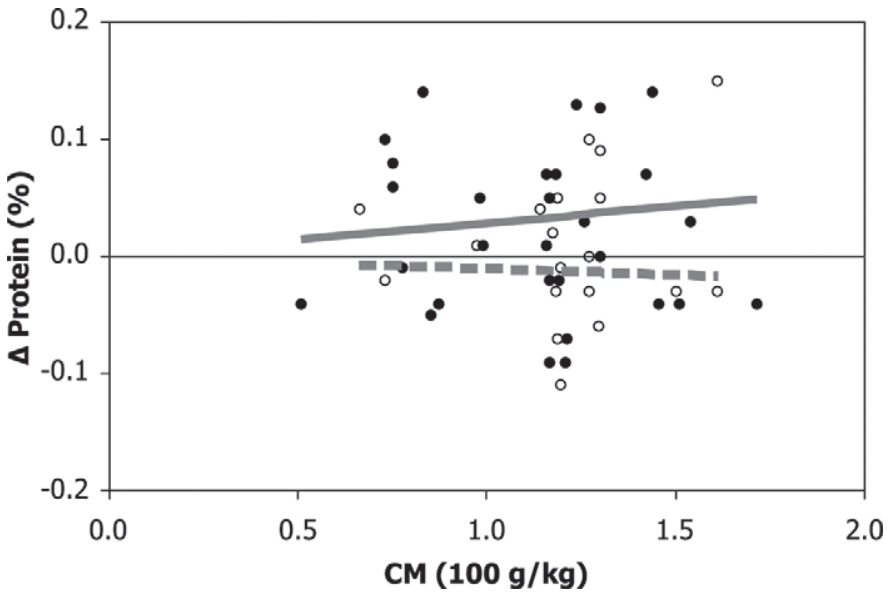

Figure 3. Effect of type of forages on responses in milk protein percentage $[\Delta$ Protein $(\%)$; canola meal $(\mathrm{CM})$ diet minus control diet] $\left(P_{\text {interaction }}=0.008\right)$ : grass/legume $[\bullet$ and solid line; $P$-value in superscript: $+0.03^{0.004}( \pm 0.009) \times \mathrm{CM}+0.13^{0.001}( \pm 0.034) \times \Delta \mathrm{CP} ; \mathrm{R}^{2}=$ $0.43 ; \mathrm{n}=30$ ] versus other forages [O and dotted line; $-0.01^{\mathrm{NS}}( \pm 0.009)$ $\left.\times \mathrm{CM}+0.08^{0.005}( \pm 0.026) \times \Delta \mathrm{CP} ; \mathrm{R}^{2}=0.40 ; \mathrm{n}=18\right]$.

substitution was positive only in studies based on grass and (or) legume forages $\left(P_{\text {interaction }}=0.073\right.$; Table 3$)$.

Origin of the Publication. One can argue that the origin of a publication is not a valid factor to consider in a meta-analysis. However, this factor was taken into consideration in the current meta-analysis because major differences were noted between North American and European studies for the type of protein supplement that was substituted and main forage fed to the cows as outlined below. For example, SBM was used mostly in North America (16 out of 23 studies) whereas other protein sources were used in Europe (14 out of 21 studies; Pearson chi-square, $P=0.016)$. The experiments based on grass and (or) legume forages were conducted mostly in Europe (21 out of 29 studies) compared with those based on other types of forages (e.g., corn or barley silage), which were conducted entirely in North America (all 15 studies; Pearson chi-square, $P<0.001$ ). Therefore, the origin of study can be seen as a mean to compare diets based on corn or barley silage plus SBM (i.e., typical North American diets in the database) with diets based on grass and (or) legume forages plus corn gluten meal, cottonseed meal, distillers product, or protein mixes (i.e., typical European diets in the database).

The response in milk protein percentage was positive only in European studies $\left(P_{\text {interaction }}=0.004\right)$, in accordance with earlier findings on type of protein source and on type of forage because positive responses were reported for grass and (or) legume forages and for supplementation of protein sources other than SBM (i.e., typical European diets in the database). The ori- 
gin of publication was not associated with the response in milk lactose percentage to substitution; however, the response in milk lactose yield to substitution was positive only in European studies $\left(P_{\text {interaction }}<0.001\right)$.

Huhtanen et al. (2011) recently published a metaanalysis comparing CM and SBM in dairy cows fed grass silage-based diets. Seven experiments with grassbased diets supplemented with either SBM or CM were extracted from the whole database. Milk yield and milk protein yield responded positively to substitution $[P$ value in superscript: $+1.16^{0.005}( \pm 0.263) \times \mathrm{CM}\left(\mathrm{R}^{2}=\right.$ $0.76 ; \mathrm{n}=7)$ and $+35.2^{0.009}( \pm 9.19) \times \mathrm{CM}\left(\mathrm{R}^{2}=0.71 ; \mathrm{n}\right.$ $=7$ ), respectively], in line with the results of Huhtanen et al. (2011). These responses are greater than those observed in the whole database, which suggest that CM feeding is a good protein supplement for grassbased diets. Indeed, His is the first-limiting AA for milk protein synthesis in cows fed grass silage-based diets supplemented with cereal concentrates (Vanhatalo et al., 1999) and His concentration is high in CM (NRC, 2001).

Estimated MP Supply. Overall, estimated total MP supplies (g/cow per day) were $+2,037$ (SD 385.6; range 1,454 to 1,$889 ; \mathrm{n}=44)$ in control diets and $+1,893$ (SD 322.3; range 1,395 to 2,$778 ; \mathrm{n}=44$ ) in $\mathrm{CM}$ diets (data not shown). Unexpectedly, given the positive responses in milk yield and milk protein yield to CM substitution, changes in supplies of total MP and MP from RUP (g/cow per day; NRC, 2001) responded negatively to $\mathrm{CM}$ substitution $[P$-value in superscript: $-71.7^{\leq 0.001}( \pm 12.11) \times \mathrm{CM}\left(\mathrm{R}^{2}=0.42, \mathrm{n}=49\right)$ and $-86.7^{\leq 0.001}( \pm 12.20) \times \mathrm{CM}\left(\mathrm{R}^{2}=0.51, \mathrm{n}=49\right)$, respectively]. Changes in estimated supply of MP from bacteria did not respond to $\mathrm{CM}$ substitution. When looking at the relationship between changes in estimated total MP supply and responses in milk protein yield (Figure 4), $60 \%$ of data points are mismatched (i.e., negative changes in MP supply are associated with positive changes in milk protein yield). Furthermore, this observation holds up even when the database is restricted to the experiments in which the $\mathrm{CP}$ concentration of $\mathrm{CM}$ is reported (i.e., closed circles in Figure 4), the latter providing a more accurate estimate of diet composition and MP.

\section{DISCUSSION}

The current meta-analysis differs from that of Huhtanen et al. (2011) on the types of studies used, inclusion criteria and other methodological aspects; as a result, only 5 publications are common to both databases. Huhtanen et al. (2011) aimed at avoiding the absence of effect sometimes observed in experiments comparing $\mathrm{CM}$ and SBM supplemented at a single rate of inclusion, especially when requirements for production were exceeded in both diets. Therefore, a criteria for inclusion in their database was that CM or SBM was used at different rates in the diet (i.e., 2 or more dietary $\mathrm{CP}$ concentrations), but did not require comparison of both CM and SBM in the same experiment. Their meta-analysis was limited to grass silage-based diets because few experiments were found in which $\mathrm{CM}$ was included at different rates in corn- or alfalfa silage-based diets. A within-experiment analysis was conducted separately for CM and SBM on the effect of increasing dietary $\mathrm{CP}$ content on the performance of dairy cows. The results for CM and SBM were then compared using a $t$-test. Regardless of the major methodological differences used in both meta-analyses, it is important to note that similar results were obtained whether the meta-analysis was conducted on varying dietary CP concentrations or on isonitrogenous diets (i.e., current meta-analysis).

Experiments using a Latin square or a crossover design were not a priori excluded from the database because only 5 studies used a randomized block design. The effect of design (Latin square vs. randomized block) was tested for each response and found not significant. Latin square or crossover designs represent a challenge in nutritional meta-analyses because of potential carryover effects from one period to another. Such carryover effects result in smaller variance of responses and they reduce the potential of finding significant differences between estimates. An example of such carryover effects was provided by Cant et al. (1997) who used a 4 $\times 4$ Latin square design with 21-d periods to determine the effect of redfish oil and monensin sodium on milk

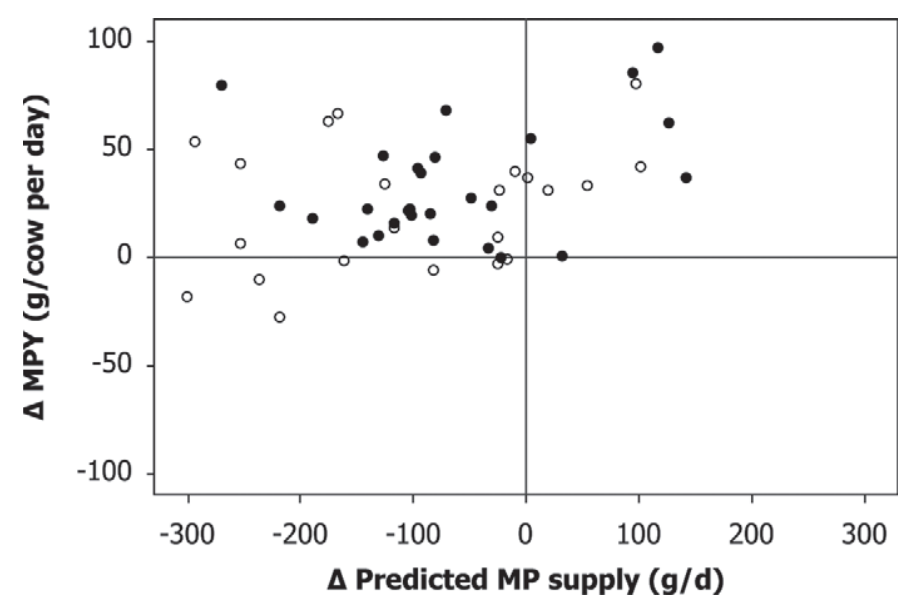

Figure 4. Relationship between responses in milk protein yield [ $\Delta$ MPY; canola meal $(\mathrm{CM})$ diet minus control diet] and changes in predicted MP supply from the NRC (2001) model $(\bullet=$ CP concentration of $\mathrm{CM}$ reported in the publication; $\mathrm{O}=\mathrm{CP}$ content of $\mathrm{CM}$ not reported in the publication). 
composition. The authors detected docosahexaenoic acid in the milk of 2 cows treated with monensin sodium at a level similar to that of cows fed redfish oil in the previous period and concluded that carryover effects could not be excluded in their experiment. Cant et al. (1997) postulated that docosahexaenoic acid was stored preferentially in adipose tissues and subsequently released over a time frame of a few weeks. Although carryover effects cannot be completely excluded from protein substitution studies, they are probably of much shorter duration. For example, responses in milk protein concentration to jugular infusion of essential AA (EAA) mixtures reach a plateau quickly (e.g., within 3 d of treatment; Metcalf et al., 1996) and are restored to initial values soon after treatment cessation (from our own observations).

The current meta-analysis was conducted on responses rather than on absolute values for 3 reasons. First, as mentioned previously, the inclusion of a quadratic term was not feasible in the within-experiment analysis because only 1 study had more than 2 data points. Second, both methods were tested in parallel and yielded similar within-experiment results given that the regression on responses was forced through the origin. Third, as can be seen in Figure 1A and B, graphs based on responses allow a better visualization of the relationships between 2 variables, especially when all experiments share the same absolute zero value.

It should be pointed out that coefficient of determination values reported in Table 3 might appear low. However, this was anticipated given the time span covered by the literature search, the different feeding regimens, and the experimental conditions varying among trials. As expected, higher coefficient of determination values were obtained when the response was tested in subset databases of significant factors or with the inclusion of 2 or more covariates.

Response in DMI to substitution was positive for the range of dietary $\mathrm{CM}$ inclusion in the database [i.e., up to $17 \%$ (DM basis)]. Experiments with CM concentrations greater than $20 \%$ can be found in the literature but they were not eligible in this meta-analysis because either N intake was missing (e.g., Andersen, 1985) or CM was not compared with another protein source [e.g., Rae et al. (1983) and Ha and Kennelly (1984)]. Emanuelson et al. (1993) cited earlier European work in which DMI was decreased with dietary proportions of CM greater than $25 \%$, irrespective of the glucosinolate content in the meal. More recently, Mancuso et al. (2002) fed cows with CM or sunflower meal at $30 \%$ of the diet and reported no difference in DMI and milk production. Given that our findings are valid only for the range of $\mathrm{CM}$ inclusion in the database, more re- search is warranted to determine the responses associated with an inclusion rate of CM greater than $17 \%$.

Even though small differences in DMI might be difficult to highlight in a single study due to lack of statistical power, significant increases were nonetheless reported when cottonseed meal (Brito and Broderick, 2007) and SBM (Vanhatalo et al., 2003; Rinne et al., 2006) were replaced by CM. The positive effect of CP supplementation on DMI has been attributed to the increased diet digestibility (Oldham, 1984). However, Huhtanen et al. (2011) reported that CM feeding increased DMI more than SBM in grass silage-based diets but with no difference in OM digestibility between CM and SBM. Huhtanen et al. (2011) postulated that DMI might increase in response to a greater energy demand due to the improved lactational performance ("pull effect") likely induced by a greater supply of AA or a more balanced profile of AA when CM was fed in place of SBM.

Overall, yields of milk, 4\% FCM, and ECM responded positively to substitution of a protein source by $\mathrm{CM}$ as most responses were positive. The magnitude of these responses was within $\pm 3 \mathrm{~kg} / \mathrm{cow}$ per day. Trends or significant increases were reported in the following studies from our database: Laarveld and Christensen (1976), Papas et al. (1978), Dewhurst et al. (1999), Shingfield et al. (2003), Vanhatalo et al.(2003), and Rinne et al. (2006).

Overall, the substitution of a protein source by CM had a positive effect on the responses in milk protein percentage and in milk protein yield. Response in milk protein percentage to substitution was positive despite a potential dilution effect caused by the increase in milk production. Although significant, the regression model accounted poorly $\left(\mathrm{R}^{2}=0.11\right)$ for the variance, suggesting that the response in milk protein percentage to substitution was variable across experiments. Indeed, a better fit to the data was obtained in subset databases separated by the type of protein source or type of forage. For example, the regression model had a better fit to the data when the database was restricted to the experiments in which protein sources other than SBM were substituted by $\mathrm{CM}\left(\mathrm{R}^{2}=0.42\right)$. Trends or significant increases in milk protein percentage were reported when CM replaced cottonseed meal (Brito and Broderick, 2007), dried distillers grains with solubles (Christen et al., 2010), untreated barley distillers solubles (Huhtanen et al., 1991), or a mixture of SBM, cottonseed meal, and coconut cake (Emanuelson et al., 1993).

Unlike the response in milk protein percentage, a much better fit to the data was obtained for the response in milk protein yield to substitution across the 
whole data set $\left(\mathrm{R}^{2}=0.59\right)$. As expected, the response was positive and significant in many publications: Huhtanen et al. (1991), Emanuelson et al. (1993), Shingfield et al. (2003), Vanhatalo et al. (2003), Rinne et al. (2006), Brito and Broderick (2007), and Oba et al. (2010).

The positive responses in milk production and in milk protein percentage and yield suggest a more efficient $\mathrm{N}$ metabolism, which might be related to a greater supply of EAA or an improvement in the duodenal profile of supplied EAA (e.g., His, Lys, and Met). In a comprehensive meta-analysis of experiments studying substitution of various protein sources (Ipharraguerre and Clark, 2005), milk protein yield was depressed by the replacement of solvent-extracted SBM by corn byproducts. The authors suggested that the effect could be attributed to the poor quality of the supplied MP due to the low Lys content of corn byproducts. Supporting the EAA profile hypothesis, the response in milk protein percentage was positive in the current meta-analysis only when CM substituted protein sources other than SBM (i.e., corn byproducts that would offer a profile of EAA not as good as SBM or CM).

Improving the quantity of potentially limiting AA or the profile of EAA in duodenal flow can be achieved by stimulating rumen microbial synthesis or by feeding protein sources that would deliver a digestible RUP fraction with an EAA profile closer to that of milk. Clark (1975) and Choung and Chamberlain (1993) demonstrated that the duodenal EAA profile should be similar to that of milk protein to increase milk protein percentage. Microbial protein has a favorable AA profile that closely matches AA requirements for milk and milk protein synthesis (NRC, 2001). Canola meal can stimulate rumen microbial synthesis because it provides an adequate supply of RDP, which is important because $\mathrm{N}$ forms other than ammonia are needed for maximum microbial growth (Griswold et al., 1996). For instance, preformed free $\mathrm{AA}$ and peptides can be readily incorporated into the microbial mass (Bach et al., 2005). The EAA profile of the digestible RUP fraction is also important as it is complementary to the supply of microbial protein. Even though canola meal supplies less duodenal RUP compared with most protein sources, it contains relatively high concentrations of Met, Lys, and His (often quoted as being limiting EAA in dairy rations) compared with other common protein sources (e.g., corn gluten meal or distillers products; NRC, 2001). Chibisa et al. (2012) found that omasal flow of bacterial NAN, as a percentage of total NAN, increased when CM replaced increasing amounts of wheat dried distillers grains with solubles, which contains much less RDP. Brito and Broderick (2007) compared CM with cottonseed meal (i.e., a poor RDP source) and reported higher MUN and urinary urea $\mathrm{N}$ excretion with $\mathrm{CM}$ compared with cottonseed meal, in accordance with the high RDP content of the $\mathrm{CM}$ diet estimated using the NRC (2001) model or measured in vivo. In contrast with this apparent loss in $\mathrm{N}$ efficiency, milk protein percentage and yield were greater with $\mathrm{CM}$ compared with cottonseed meal, thus reflecting an overall improved $\mathrm{N}$ metabolism. In a companion paper, Brito et al. (2007) reported that omasal NAN flows (\% of $\mathrm{N}$ intake) were similar for CM and cottonseed meal but that CM supplied less RUP (\% of DMI) and more microbial NAN (\% of total NAN) compared with cottonseed meal. These results suggest that $\mathrm{CM}$ improved milk protein percentage and yield due to better quality of EAA in omasal NAN flow and that the AA profile of RUP from cottonseed meal might not be complementary to that of microbial protein. Indeed, CM has a greater Lys content compared with cottonseed meal (NRC, 2001) and, although omasal Lys flows were similar for CM and cottonseed meal (Brito et al., 2007), metabolizable Lys could differ between diets depending on the intestinal digestibility coefficient applied for Lys.

Several responses to substitution were clearly better when CM replaced protein sources other than SBM (as opposed to CM vs. SBM): greater response in $4 \% \mathrm{FCM}$ and ECM, greater response in milk protein percentage and yield, as well as greater milk and apparent $\mathrm{N}$ efficiencies. The response in milk protein yield was 2 times greater when $\mathrm{CM}$ replaced protein sources other than SBM: this suggests that the EAA profile of SBM might be more balanced or complementary to that of microbial protein compared with the EAA profile of other protein sources (e.g., distillers grain, corn gluten meal, and cottonseed meal). Indeed, it must be acknowledged that substitution of CM by other protein sources may have altered not just the supply of AA but also the provision of carbohydrates, FA, minerals, and vitamins, all of them potentially contributing to the effects observed. However, the scarcity of details about diet composition precluded a thorough examination of the contribution of these factors on the responses to CM substitution.

In a further attempt to determine why CM had an overall positive effect on milk production, estimated MP supply was calculated with the NRC (2001) model, as diets might be isonitrogenous but have different MP supply. A good relationship was expected between changes in MP supply and changes in milk protein secretion, given that MP supply is a key factor that determines milk protein secretion in lactating dairy cows (NRC, 2001; Broderick et al., 2010). However, MP supply appeared underestimated in CM diets, as most positive changes in milk protein yield were coupled with negative changes in estimated MP supply. Huhtanen et al. (2011) also had concerns about accuracy of most 
feed evaluation systems in estimating MP supply and reported that these systems usually underestimate MP concentration of CM relative to SBM. A low estimation of MP supply by CM can result from low estimations of either microbial synthesis or RUP, and also from low intestinal digestibility of RUP (\% of RUP). Brito et al. (2007) reported a lower estimation of microbial protein synthesis by $14 \%$ using NRC (2001) model compared with in vivo estimations using ${ }^{15} \mathrm{~N}$ in omasal samples. The authors speculated that the discrepancy might be due to low purine recovery, thus biasing estimations of total purines, which are the primary microbial marker used for the microbial protein measurements in many studies included in the NRC (2001) database. Furthermore, Brito et al. (2007) pointed out that variations in prediction of microbial synthesis might occur because many factors affecting microbial synthesis were not accounted for in the NRC (2001) model (e.g., form of N available in the rumen, source and amount of carbohydrate, amount and source of fat, ruminal $\mathrm{pH}$, and dilution rate). This would negatively affect estimated MP supply of high-RDP protein sources such as CM, especially when compared with less-degradable protein sources (e.g., corn gluten meal, cottonseed meal, and distillers products). The intestinal digestibility of RUP of the expeller CM used by NRC (2001) is relatively low ( $75 \%$ of RUP) compared with that of other protein sources (e.g., $93 \%$ for mechanically or solvent-extracted SBM and $92 \%$ for cottonseed meal). For example, in Brito and Broderick (2007), changes in estimated MP supply were approximately -140 and $-270 \mathrm{~g} /$ cow per day (calculated values not reported in the article) when CM replaced solvent SBM and cottonseed meal, respectively. These negative MP supplies were associated with positive responses in milk protein yield. Increasing the intestinal digestibility of RUP of CM from 75 to $85 \%$ of RUP would add approximately $60 \mathrm{~g}$ to the supply of MP from CM. The intestinal digestibility of RUP of CM should be investigated further, given that it could account for a nonnegligible part of the discrepancy observed between changes in estimated MP supply and responses in milk protein yield.

\section{CONCLUSIONS}

The present meta-analysis was based on experiments using isonitrogenous diets $( \pm 1 \%$ dietary $\mathrm{CP}$ between the control and the treatment diets) in which CM substituted a protein source in dairy rations. Dry matter intake responded positively to substitution; therefore, all regressions were controlled for differences in DMI and differences in dietary $\mathrm{CP}$ and $\mathrm{EE}$ concentrations between the control and the CM diet. Yields of milk, $4 \%$ FCM, and ECM, as well as yields of milk protein and fat responded positively to substitution. Furthermore, milk protein percentage also responded positively to substitution. Among the experimental conditions or factors that significantly influenced the responses to substitution, it is noteworthy to mention the type of forage (e.g., grass or legume forages vs. corn or barley silage) and the type of protein substituted (SBM or other protein sources). Milk protein percentage responded positively when cows were fed grass or legume forages but the response was not significant when cows were fed other forages. On the other hand, responses in yields of $4 \%$ FCM and ECM, milk protein percentage and yield, milk efficiency, and apparent $\mathrm{N}$ efficiency were all positive or greater when CM replaced a protein source based on corn gluten meal, cottonseed meal, distillers product, or a protein mix that included or not some SBM. Milk protein yield and apparent N efficiency responded positively to substitution, suggesting an increment in duodenal MP supplied or a better profile of duodenal EAA. However, most positive responses in milk protein yield were coupled with negative changes in estimated MP supply, reflecting a systematic underestimation of MP supply associated with CM inclusion in dairy rations in the current database using the NRC (2001) model.

\section{ACKNOWLEDGMENTS}

Sincere thanks to the Canola Council of Canada (Winnipeg, MB, Canada) and Agriculture and AgriFood Canada (Sherbrooke, QC, Canada) for funding this research.

\section{REFERENCES}

Abbadi, A., and G. Leckband. 2011. Rapeseed breeding for oil content, quality, and sustainability. Eur. J. Lipid Sci. Technol. 113:11981206.

Andersen, P. E. 1985. Double low rapeseed meal in diets to dairy cows. Pages 218-221 in Advances in the Production and Utilization of Cruciferous Crops. H. Sørensen, ed. Martinus Nijhoff Publishers, The Hague, the Netherlands.

Bach, A., S. Calsamiglia, and M. D. Stern. 2005. Nitrogen metabolism in the rumen. J. Dairy Sci. 88(E Suppl.):E9-E21.

Bauman, D. E., and J. M. Griinari. 2003. Nutritional regulation of milk fat synthesis. Annu. Rev. Nutr. 23:203-227.

Bell, J. M. 1984. Nutrients and toxicants in rapeseed meal: A review. J. Anim. Sci. 58:996-1010.

Brito, A. F., and G. A. Broderick. 2007. Effects of different protein supplements on milk production and nutrient utilization in lactating dairy cows. J. Dairy Sci. 90:1816-1827.

Brito, A. F., G. A. Broderick, and S. M. Reynal. 2007. Effects of different protein supplements on omasal nutrient flow and microbial protein synthesis in lactating dairy cows. J. Dairy Sci. 90:18281841.

Broderick, G. A., P. Huhtanen, S. Ahvenjärvi, S. M. Reynal, and K. J. Shingfield. 2010. Quantifying ruminal nitrogen metabolism using the omasal sampling technique in cattle-A meta-analysis. J. Dairy Sci. 93:3216-3230. 
Cant, J. P., A. H. Fredeen, T. MacIntyre, J. Gunn, and N. Crowe. 1997. Effect of fish oil and monensin on milk composition in dairy cows. Can. J. Anim. Sci. 77:125-131.

Chibisa, G. E., D. A. Christensen, and T. Mutsvangwa. 2012. Effects of replacing canola meal as the major protein source with wheat dried distillers grains with solubles on ruminal function, microbial protein synthesis, omasal flow, and milk production in cows. J. Dairy Sci. 95:824-841.

Choung, J.-J., and D. G. Chamberlain. 1993. The effects of abomasal infusions of casein or soya-bean-protein isolate on the milk production of dairy cows in mid-lactation. Br. J. Nutr. 69:103-115.

Christen, K. A., D. J. Schingoethe, K. F. Kalscheur, A. R. Hippen, K. K. Karges, and M. L. Gibson. 2010. Response of lactating dairy cows to high protein distillers grains or 3 other protein supplements. J. Dairy Sci. 93:2095-2104.

Christensen, D. A., and P. J. McKinnon. 1989. Canola meal for beef and dairy cattle. Pages 19-22 in Canola Meal for Livestock and Poultry. D. R. Clandinin, ed. Canola Council of Canada, Winnipeg, MB, Canada.

Clark, J. H. 1975. Lactational responses to postruminal administration of proteins and amino acids. J. Dairy Sci. 58:1178-1197.

Cook, R. D. 1979. Influential observations in linear regression. J. Am. Stat. Assoc. 74:169-174.

DePeters, E. J., and D. L. Bath. 1986. Canola meal versus cottonseed meal as a protein supplement in dairy rations. J. Dairy Sci. 69:148-154.

Dewhurst, R. J., K. Aston, W. J. Fisher, R. T. Evans, M. S. Dhanoa, and A. B. McAllan. 1999. Comparison of energy and protein sources offered at low levels in grass-silage-based diets for dairy cows. Anim. Sci. 68:789-799.

Emanuelson, M. 1989. Rapeseed Products of Double Low Cultivars to Dairy Cows: Effects of Long-Term Feeding and Studies on Rumen Metabolism. Volume 189 of Rapport. Swedish University of Agricultural Sciences, Department Animal Nutrition Management, Uppsala, Sweden.

Emanuelson, M., K.-Å. Ahlin, and H. Wiktorsson. 1993. Long-term feeding of rapeseed meal and full-fat rapeseed of double low cultivars to dairy cows. Livest. Prod. Sci. 33:199-214.

Fenwick, G. R. 1982. The assessment of a new protein source-Rapeseed. Proc. Nutr. Soc. 41:277-288.

Fisher, L. J., and D. S. Walsh. 1976. Substitution of rapeseed meal for soybean meal as a source of protein for lactating cows. Can. J. Anim. Sci. 56:233-242.

Gaines, W. L. 1928. The energy basis of measuring milk yield in dairy cows. Illinois Agric. Expt. Sta., Bull. No. 308:401-438. University of Illinois Agricultural Experiment Station, Urbana.

Glasser, F., A. Ferlay, and Y. Chilliard. 2008. Oilseed lipid supplements and fatty acid composition of cow milk: A meta-analysis. J. Dairy Sci. 91:4687-4703.

Grenet, N., and M. Journet. 1971. Rapeseed oil meal in animal feeding. III. Influence of the processing method and the proportion of oil meal in concentrate fed to dairy cows on feed intake, milk production and composition. Ann. Zootech. 20:437-449.

Griswold, K. E., W. H. Hoover, T. K. Miller, and W. V. Thayne. 1996. Effect of form of nitrogen on growth of ruminal microbes in continuous culture. J. Anim. Sci. 74:483-491.

Ha, J. K., and J. J. Kennelly. 1984. Effect of protein on nutrient digestion and milk production by Holstein cows. J. Dairy Sci. 67:2302-2307.

Harker, K. N., J. T. O'Donovan, T. K. Turkington, R. E. Blackshaw, N. Z. Lupwayi, E. G. Smith, H. Klein-Gebbinck, L. M. Dosdall, L. M. Hall, C. J. Willenborg, H. R. Kutcher, S. S. Malhi, C. L. Vera, Y. Gan, G. P. Lafond, W. E. May, C. A. Grant, and D. L. McLaren. 2012. High-yield no-till canola production on the Canadian prairies. Can. J. Plant Sci. 92:221-233.

Hickling, D. 2008. Maximized utilization of canola co-products in livestock industry. Pages 3-14 in Proc. 29th Western Nutrition Conference, Edmonton, AB, Canada. University of Alberta, Edmonton, AB, Canada.

Hill, R. 1991. Rapeseed meal in the diets of ruminants. Nutr. Abstr. Rev. 61:139-155. (Series B).
Huhtanen, P. 1998. Supply of nutrients and productive responses in dairy cows given diets based on restrictively fermented silage. Agric. Food Sci. 7:219-250.

Huhtanen, P., M. Hetta, and C. Swensson. 2011. Evaluation of canola meal as a protein supplement for dairy cows: A review and a metaanalysis. Can. J. Anim. Sci. 91:529-543.

Huhtanen, P., S. Jaakkola, and E. Saarisalo. 1995. The effects of concentrate energy source on the milk production of dairy cows given a grass silage-based diet. Anim. Sci. 60:31-40.

Huhtanen, P., H. Khalili, and M. Näsi. 1991. A comparison of untreated and formaldehyde-treated barley distiller's solubles and rapeseed meal as protein supplements in dairy cows given grass silage ad libitum. J. Agric. Sci. Finland 63:455-463.

Ingalls, J. R., and H. R. Sharma. 1975. Feeding of Bronowski, Span and commercial rapeseed meals with or without addition of molasses or flavor in the rations of lactating cows. Can. J. Anim. Sci. 55:721-729.

Ipharraguerre, I. R., and J. H. Clark. 2005. Impacts of the source and amount of crude protein on the intestinal supply of nitrogen fractions and performance of dairy cows. J. Dairy Sci. 88(Suppl. 1):E22-E37.

Khalili, H., A. Sairanen, K. Hissa, and P. Huhtanen. 2001. Effects of type and treatment of grain and protein source on dairy cow performance. Anim. Sci. 72:573-584.

Khorasani, G. R., P. H. Robinson, and J. J. Kennelly. 1994. Evaluation of solvent and expeller linseed meals as protein sources for dairy cattle. Can. J. Anim. Sci. 74:479-485.

Kleinbaum, D. G., L. L. Kupper, K. E. Muller, and A. Nizam. 1998. Confounding and interaction in regression. Pages 186-211 in Applied Regression Analysis and Other Multivariable Methods. G. Kleinbaum, L. L. Kupper, A. Nizam, and K. E. Muller, ed. Duxbury Press, Pacific Grove, CA.

Laarveld, B., and D. A. Christensen. 1976. Rapeseed meal in complete feeds for dairy cows. J. Dairy Sci. 59:1929-1935.

Littell, R. C., G. A. Milliken, W. W. Stroup, and R. D. Wolfinger. 1996. SAS ${ }^{\circledR}$ system for mixed models. SAS Institute, Cary, NC.

Lusas, E. E., and M. N. Riaz. 2005. Fats and oils in feedstuffs and pet foods. Pages 317-390 in Bailey's Industrial Oil \& Fat Product. 6th ed. F. Shahidi, ed. John Wiley \& Sons, New York, NY.

Macleod, G. K. 1991. Canola meal as a protein supplement in corn based dairy rations. Pages 255-264 in Research on Canola Seed, Oil, and Meal. Ninth Project Report. Canola Council of Canada, Winnipeg, MB, Canada.

Mancuso, W. A., F. J. Santini, G. A. Gagliostro, and D. H. Rearte. 2002. Supplementacíon con harina de girasol o de colza "00" a vacas lecheras alimentadas con dietas en base a silaje de maíz. Rev. Arg. Prod. Anim. 22:169-184.

McClean, C., and B. Laarveld. 1991. Effect of somatotropin and protein supplement on thyroid function of dairy cattle. Can. J. Anim. Sci. 71:1053-1061.

Metcalf, J. A., L. A. Crompton, D. Wray-Cahen, M. A. Lomax, J. D. Sutton, D. E. Beever, J. C. MacRae, B. J. Bequette, F. R. C. Backwell, and G. E. Lobley. 1996. Responses in milk constituents to intravascular administration of two mixtures of amino acids to dairy cows. J. Dairy Sci. 79:1425-1429.

Moss, A. 2002. The effects of long-term feeding of extracted rapeseed meal and whole rapeseed on the physical and financial performance, health and welfare of high yielding dairy cows. HGCA Project Report OS59. Home Grown Cereals Authority, London, UK.

Mulrooney, C. N., D. J. Schingoethe, K. F. Kalscheur, and A. R. Hippen. 2009. Canola meal replacing distillers grains with solubles for lactating dairy cows. J. Dairy Sci. 92:5669-5676.

Munger, A. 1996. Use of rapeseed oilmeal concentrates in dairy cow feeding. Revue Suisse d'Agriculture 28:133-136.

NRC. 2001. Nutrient Requirements of Dairy Cattle. 7th rev. ed. National Academy of Sciences, Washington, DC.

Newkirk, R. 2009. Canola Meal: Feed Industry Guide. 4th ed. Canadian International Grains Institute, Winnipeg, MB, Canada.

Oba, M., G. B. Penner, T. D. Whyte, and K. Wierenga. 2010. Effects of feeding triticale dried distillers grains plus solubles as a nitro- 
gen source on productivity of lactating dairy cows. J. Dairy Sci. 93:2044-2052.

Oldham, J. D. 1984. Protein-energy interrelationships in dairy cows. J. Dairy Sci. 67:1090-1114.

Papas, A., J. R. Ingalls, and P. Cansfield. 1978. Effects of Tower and 1821 rapeseed meals and Tower gums on milk yield, milk composition and blood parameters of lactating dairy cows. Can. J. Anim. Sci. 58:671-679.

Piepenbrink, M. S., D. J. Schingoethe, M. J. Brouk, and G. A. Stegeman. 1998. Systems to evaluate the protein quality of diets fed to lactating cows. J. Dairy Sci. 81:1046-1061.

Rae, R. C., J. R. Ingalls, and J. A. McKirdy. 1983. Response of dairy cows to formaldehyde-treated canola meal during early lactation. Can. J. Anim. Sci. 63:905-915.

Rinne, M., K. Kuoppala, S. Ahvenjärvi, and A. Vanhatalo. 2006. Rypsi soijaa parempi lypsylehmien valkuaistäydennys myös apilapitoista säilörehua syötettäessä. In Maataloustieteen päivät 2006. Suomen Maataloustieteellisen Tiedote 21:1-7. A. Hopponen, ed. Accessed Oct. 5, 2011. http://www.smts.fi/esit06/1002.pdf.

Robinson, P. H., and J. J. Kennelly. 1988. Influence of intake of rumen undegradable protein on milk production of late lactation Holstein cows. J. Dairy Sci. 71:2135-2142.

Sauvant, D., P. Schmidely, J. J. Daudin, and N. R. St-Pierre. 2008. Meta-analyses of experimental data: Application in animal nutrition. Animal 2:1203-1214.

Sharma, H. R., J. R. Ingalls, and J. A. McKirdy. 1977. Effects of feeding a high level of Tower rapeseed meal in dairy rations on feed intake and milk production. Can. J. Anim. Sci. 57:653-662.

Shingfield, K. J., S. Jaakkola, and P. Huhtanen. 2001. Effects of level of nitrogen fertilizer application and various nitrogenous supplements on milk production and nitrogen utilization of dairy cows given grass silage-based diets. Anim. Sci. 73:541-554.

Shingfield, K. J., A. Vanhatalo, and P. Huhtanen. 2003. Comparison of heat-treated rapeseed expeller and solvent-extracted soya-bean meal as protein supplements for dairy cows given grass silagebased diets. Anim. Sci. 77:305-317.
Sjaunja, L. O., L. Baevre, L. Junkkarinen, J. Pedersen, and J. Setälä 1990. A Nordic proposal for an energy corrected milk (ECM) formula. Pages 156-157 in Proceedings of the 27th Session of the International Committee of Recording and Productivity of Milk Animal. EEAP Publication No. 50. P. Gaillon and Y. Chabert, ed. Pudoc, Wageningen, the Netherlands.

St-Pierre, N. R. 2001. Invited review: Integrating quantitative findings from multiple studies using mixed model methodology. J. Dairy Sci. 84:741-755.

Stefansson, B. R., and Z. P. Kondra. 1975. Tower summer rape. Can. J. Plant Sci. 55:343-344.

Tan, S. H., R. J. Mailer, C. L. Blanchard, and S. O. Agboola. 2011. Canola proteins for human consumption: Extraction, profile, and functional properties. J. Food Sci. 76:R16-R28.

Thomke, S. 1981. Review of rapeseed meal in animal nutrition: Ruminant animals. J. Am. Oil Chem. Soc. 58:805-810.

Tuori, M. 1992. Rapeseed meal as a supplementary protein for dairy cows on grass silage-based diet, with the emphasis on the Nordic AAT-PBV feed protein evaluation system. Agric. Sci. Finland $1: 375-439$.

Vanhatalo, A., P. Huhtanen, V. Toivonen, and T. Varvikko. 1999. Response of dairy cows fed grass silage diets to abomasal infusions of histidine alone or in combinations with methionine and lysine. J. Dairy Sci. 82:2674-2685.

Vanhatalo, A., E. Pahkala, P. Salo-Väänänen, H. Korhonen, V. Piironen, and P. Huhtanen. 2003. Rapeseed and soybean as protein supplements of dairy cows fed grass silage based diets. Pages 1238-1240 in Proc. 11th Intl. Rapeseed Congress: Enhanced Value of Cruciferous Oilseed Crops by Optimal Production and Use of the High Quality Seed Components. H. Sørensen, J. C. Sørensen, S. Sørensen, N. Bellostas Muguerza, and C. Bjergegaard, ed. The Royal Veterinary and Agricultural University, Copenhagen, Denmark. 